\title{
Adapting to the inevitable
}

Greenhouse-gas emissions targets to be disc ussed in Buenos Aires next month will have little effect on the potential impacts of climate change. We should be exploring ways of adapting to impacts, some of $w$ hic $h$ are inevitable.

\section{Martin Parry, Nigel A rnell, \\ Mike Hulme, Robert Nic holls and Matthew Livermore}

In Kyoto last December, at the third conference of the United Nations Framework Convention on Climate Change, targets were agreed for reductions in greenhouse-gas emissions. On 2 November in Buenos Aires, negotiators will reconvene at the framework convention's fourth conference to agree the mechanisms and a timetable for implementation. We shall be hearing a good deal about trading permits, compliance and enforcement in the weeks to come. But, in reality, the control of global warming that can be achieved on the current agenda is verylimited.

The Kyoto Protocol is an agreement to a 5.2 per cent reduction in greenhouse-gas emissions by about 2010 (relative to 1990), and constant emissions thereafter. But these targets only relate to the so-called annex 1 countries (38 industrialized nations). These countries together account for about 57 per cent of present global carbon emissions, but will produce only 25 per cent of the emissions growth over the next 20 years. Most future growth in emissions is expected to occur in the fast-developing regions of Asia and Latin America, which are not signatories to the framework convention.

As a consequence, the Kyoto target itself does relatively little to combat the rate of climate change. The warming expected by 2050 , without any deliberate mitigation, is estimated by the Intergovernmental Panel on Climate Change (IPCC) at $1.4^{\circ} \mathrm{C}$ with respect to the $1961-90$ average $^{1}$. About $0.25^{\circ} \mathrm{C}$ of this has already been realized by the 1990 s. Our model predictions suggest that fully implemented Kyoto targets would reduce this global warming by 2050 only by about $0.05^{\circ} \mathrm{C}$. Even more radical targets, such as a 20 per cent reduction in greenhouse-gas emissions from annex 1 countries, would reduce it by only a further $0.1^{\circ} \mathrm{C}$ by 2050 .

These minor reductions in the expected warming mean that the projected impacts of change are barely affected. The global number of people put at increased risk of hunger, water shortage or coastal flooding during storms as a result of projected climate changes is hardly touched by the targets under discussion at Buenos Aires, even if full implementation of the targets is agreed there. The numbers in Table 1 are derived from models reported at Kyoto ${ }^{2}$. Although, for example, an extra 23 million people could be affected by coastal storm flooding due to sea-level rise without any mitigation,

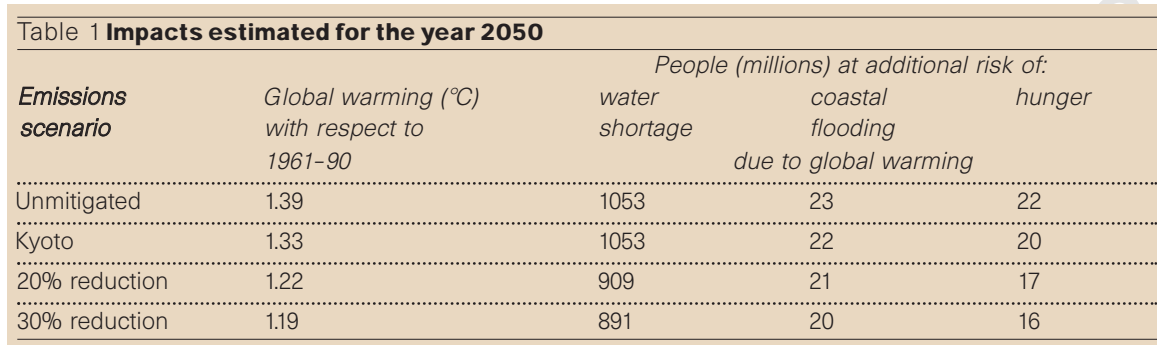

perhaps one million might avoid such flooding as a result of achieving the Kyoto target.

The convention calls on signatories to take action to safeguard food security, ecosystems and sustainable development from dangerous levels of climate change. But the current target does not do this. This does not mean that we should despair, but it emphasizes two things. First, Kyoto and Buenos Aires are only the first steps in a process that must involve much greater reduction in emissions and also, crucially, the participation of developing countries. In this respect, the achievements of the industrialized countries at Kyoto, if ratified, are important in providing a lead that will encourage others to follow. Second, mitigation by reducing greenhouse-gas emissions cannot be the entire response to the threat of climate change. Given the long history of past emissions from industrialized countries and the inertia of the climate system, we will experience a substantial amount of further climate change even if we make huge cuts.

We should, therefore, be thinking seriously about how we can best adapt to climate change. Although article 3 of the convention calls upon signatories to take steps to reduce climate impacts, adaptation has received very little attention compared with mitigation. This may be partly because to admit the need to adapt sounds defeatist to negotiators, and also because adaptation seems more complicated than mitigation (emissions sources are relatively few, but the array of adaptations is vast). Yet to ignore adaptation is both unrealistic and perilous.

Moreover, there are two very sound reasons why we should seek global agreement on adaptation. First, our current vulnerabili-

\begin{tabular}{|c|c|c|c|}
\hline $\begin{array}{l}\text { Table } 2 \text { Effec } \\
\text { on global imp }\end{array}$ & $\begin{array}{l}\text { cts of } \\
\text { pacts }\end{array}$ & $\begin{array}{l}\text { cing } \\
\text { nat }\end{array}$ & $\begin{array}{l}\text { for } w \text { ater } \\
\text { by } 2050\end{array}$ \\
\hline $\begin{array}{l}\text { Emissions } \\
\text { scenario }\end{array}$ & $\begin{array}{l}\text { Peop } \\
\text { wate } \\
\text { in de }\end{array}$ & $\begin{array}{l}\text { illions } \\
\text { ortage } \\
\text { d for n }\end{array}$ & $\begin{array}{l}\text { onal risk of } \\
\text { change }\end{array}$ \\
\hline & $0 \%$ & $-5 \%$ & $-10 \%$ \\
\hline Unmitigated & 1053 & 445 & 131 \\
\hline Kyoto & 1053 & 445 & 131 \\
\hline $20 \%$ reduction & 909 & 349 & 125 \\
\hline $30 \%$ reduction & 891 & 349 & -200 \\
\hline
\end{tabular}

ty to existing climatic variability is very costly. For instance, about 640 million people are at risk of hunger now. Poverty is the root cause, but much of the year-to-year variability in hunger is due to drought. By droughtproofing those at risk now we could secure their present livelihood and reduce the impact of future climate change. There are many kinds of such 'win-win' solutions that serve both our present and future needs, such as increasing irrigation efficiency, breeding more drought-resistant crops and developing buffer stocks of food.

Second, adapting to climatic variability has a substantially greater effect of reducing impact than does mitigation. Consider, for example, the effect of reducing water demand, shown in Table 2 as being reduced in each country by 5 and 10 per cent below current projections for 2050. Reducing water demand by just 5 per cent has four times as great an effect as reducing emissions by 30 per cent. Broadly, the same stress-reducing outcomes would stem from similar demand reductions in other impact sectors (such as reducing soil erosion, or reducing crop yield losses to pests and diseases).

There is a risk that negotiators have lost sight of the ultimate objective of the convention, which is to avoid dangerous levels of climate change. Current mitigation targets will not achieve this and should not be mistaken for effective climate management. The other 'half' of the convention - action to reduce impacts - needs to be considered at the same time.

Martin Parry and Matthew Livermore are at the Jackson Environment Institute, University College London, 5 Gower Street, London WC1E 6HA, UK. Nigel Arnell is in the Department of Geography, University of Southampton, Southampton SO17 1BJ, UK. Mike Hulme is at the Climatic Research Unit, University of East Anglia, Norwich NR4 7TJ, UK. Robert Nicholls is at the Flood Hazard Research Centre, Middlesex University, Enfield EN3 4SF, UK. They are lead authors of the IPCC.

1. Intergovernmental Panel on Climate Change. Climate Change 1995: The Science of Climate Change (Cambridge Univ. Press, Cambridge, 1996).

2. Department of the Environment, Transport and the Regions. Climate Change and its Impacts (DETR, London, 1997). 